\title{
Coumarin Sulfonamides and Amides Derivatives: Design, Synthesis, and Antitumor Activity In Vitro
}

\author{
Jing Zhang ${ }^{1}$, Yaling Tan ${ }^{1}$, Guorong Li ${ }^{1}$, Lexian Chen ${ }^{1}$, Minyi Nie ${ }^{1}$, Zhaohua Wang ${ }^{2}$ and Hong $\mathrm{Ji}^{1, *}$ \\ 1 Key Laboratory of Molecular Target \& Clinical Pharmacology and the State Key Laboratory of Respiratory \\ Disease, School of Pharmaceutical Sciences \& the Fifth Affiliated Hospital, Guangzhou Medical University, \\ Guangzhou 511436, China; ZhangJingde163yx@163.com (J.Z.); tanyalinglove@163.com (Y.T.); \\ 13423686258@163.com (G.L.); chenlexian666@163.com (L.C.); nieminyi6@163.com (M.N.) \\ 2 School of Basic Medical Sciences, Guangzhou Medical University, Guangzhou 511436, China; \\ gy_wzhh@163.com \\ * Correspondence: hji@gzhmu.edu.cn; Tel.: +86-20-37103256
}

check for updates

Citation: Zhang, J.; Tan, Y.; Li, G.;

Chen, L.; Nie, M.; Wang, Z.; Ji, H.

Coumarin Sulfonamides and Amides Derivatives: Design, Synthesis, and Antitumor Activity In Vitro. Molecules 2021, 26, 786. https://doi.org/ $10.3390 /$ molecules 26040786

Academic Editors: Maria João Matos and Claudiu T. Supuran

Received: 17 January 2021

Accepted: 28 January 2021

Published: 3 February 2021

Publisher's Note: MDPI stays neutral with regard to jurisdictional claims in published maps and institutional affiliations.

Copyright: (c) 2021 by the authors. Licensee MDPI, Basel, Switzerland. This article is an open access article distributed under the terms and conditions of the Creative Commons Attribution (CC BY) license (https:// creativecommons.org/licenses/by/ $4.0 /)$.

\begin{abstract}
Coumarins possesses immeasurable antitumor potential with minimum side effects depending on the substitutions on the basic nucleus, which exhibits great prospects for antitumor drug development. In an attempt to develop novel antitumor candidates, a series of coumarin sulfonamides and amides derivatives were designed and synthetized. The majority of these derivatives showed good cytotoxic activity against MDA-MB-231 and KB cell lines, among which compound 9c was the most potent against MDA-MB-231 cells, with $\mathrm{IC}_{50}$ value of $9.33 \mu \mathrm{M}$, comparable to 5-fluorouracil. Further investigation revealed that compound $9 \mathrm{c}$ had versatile properties against tumors, including inhibition of cell migration and invasion as well as inducing apoptosis. Reactive oxygen species (ROS) assay and western blotting analysis suggested that compound 9c promoted cancer cell apoptosis by increasing ROS levels and upregulating the expression of caspase- 3 in MDA-MB-231 cells. These results indicated that compound $9 \mathrm{c}$ could be promising lead compound for further antitumor drug research.
\end{abstract}

Keywords: coumarin sulfonamides; coumarin amides; MDA-MB-231; antitumor

\section{Introduction}

Cancer is a widespread and lethal disease characterized by uncontrolled growth of abnormal cells. It has been expected to be the leading cause of death in the future [1,2]. Although cancer research resulted in a range of innovative and promising therapeutic approaches, the existing drugs for cancer treatment are frequently associated with several drawbacks such as severe side effects, multidrug resistance, poor bioavailability. Therefore, there is an urgent need for the development of more effective and safer anticancer agents.

Coumarins are a wide family of secondary metabolites found in various species of plants but also fungi and microorganisms [3,4], which exhibit diverse pharmacological effects, especially anticancer activity [5-7]. Many coumarins and their derivatives have attracted considerable attention as cancer chemopreventive agents and also as cancer therapeutics [8-14]. Additionally, they have several attractive features, such as low molecular weight, simple structure, high bioavailability, high solubility in most of the organic solvents, and low toxicity, which ensure them a prominent role as lead compounds in drug research and development [15].

The promising biological profile of coumarins as antitumor agents and their easy synthetic modifications paved the way for design and synthesis of various coumarin derivatives $[16,17]$. In the last decade, coumarin derivatives have been increasingly reported to possess antitumor activity through different pharmacological mechanisms, among which coumarin sulfonamides and amides derivatives have attracted great interest because of their potency. Sabt et al. reported a series of novel coumarin-6-sulfonamides as antiproliferative agents [18] and found that compound I (Figure 1) was able to induce apoptosis 
in HepG2 cells by the upregulation of Bax and downregulation of $\mathrm{Bcl}-2$, besides boosting caspase-3 levels. Yu et al. identified compound II as a potent inhibitor of the Hsp90 protein-folding machinery [19]. Compound III was founded to be a promising LOX and hCA IX inhibitor [20].

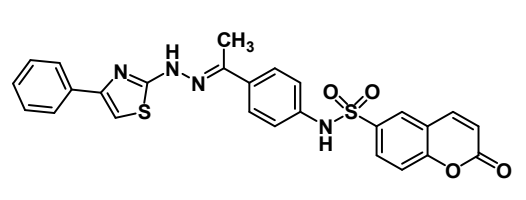

I

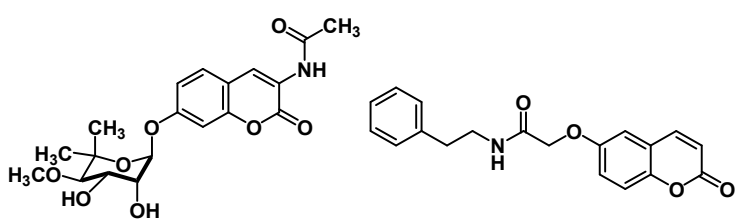

II

III

Figure 1. Chemical structures of compounds I-III.

In order to discover more potent and selective antitumor agents for further development and as a continuation of our previous studies [21], we designed and synthesized coumarin derivatives bearing sulfonamide and amide moieties. Their cytotoxic activity was screened, and the antitumor effects of the most potent compound on MDA-MB-231 cell line were further investigated.

\section{Results}

\subsection{Chemical Synthesis}

The synthesis of coumarin sulfonamides derivatives $7 \mathbf{a}-\mathbf{7 b}$ and $\mathbf{9 a}-\mathbf{9 c}$ were outlined in Scheme 1. Compound 3 were obtained by the sulfonylation of the commercially available aromatic amine $\mathbf{1}$ with methyl 2-chlorosulfonylacetate $\mathbf{2}$ in triethylamine at room temperature. The alkylation of 2,4-dihydroxybenzaldehyde 4 with bromide 5 in anhydrous DMF at $110{ }^{\circ} \mathrm{C}$ provided compound 6 . The condensation of compound 3a with substituted salicylaldehyde 6 in anhydrous ethanol in the presence of piperidine gave coumarin sulfonamides $7 \mathbf{a}-7 \mathbf{b}$. The reaction of compound $\mathbf{3}$ and 4 -(diethylamino) salicylaldehyde 8 in the same condition afforded the desired compound 9 . The coumarin amides derivatives 12a-12c were synthesized as described in Scheme 2. The ethyl coumarin-3-carboxylate 11 was prepared by the condensation of 4-(diethylamino) salicylaldehyde 8 with ethyl malonate $\mathbf{1 0}$ in anhydrous ethanol in the presence of piperidine. The ammonolysis of compound $\mathbf{1 1}$ with aromatic amines $\mathbf{1}$ in anhydrous ethanol under reflux led to desired compound 12.

\subsection{Cytotoxicity}

The in vitro cytotoxicity of the synthesized compounds (Table 1) was evaluated using MTT assay against three human cancer cell lines MDA-MB-231 (human breast cancer cell line), KB (human oral epidermoid carcinoma cell line), and HCT-116 (human colon cancer cell line). 5-Fluorouracil was included as positive control. As shown in Table 2, the majority of the compounds exhibited good inhibitory activities against MDA-MB-231 and KB cell lines, while weak cytotoxicity was observed against HCT-116 cell line except for compounds $9 \mathbf{a}$ and $\mathbf{9 b}$. Almost all the compounds were more active than 5-fluorouracil against KB cells. In particular, compounds $9 \mathbf{b}, \mathbf{9 c}$ and $\mathbf{1 2 b}$ showed stronger inhibitory effects than the rest of the compounds. The most potent compound $9 \mathrm{c}$ with the $\mathrm{IC}_{50}$ values of 9.33 and $13.66 \mu \mathrm{M}$ against MDA-MB-231 and KB cells, respectively, was chosen for further investigation. 

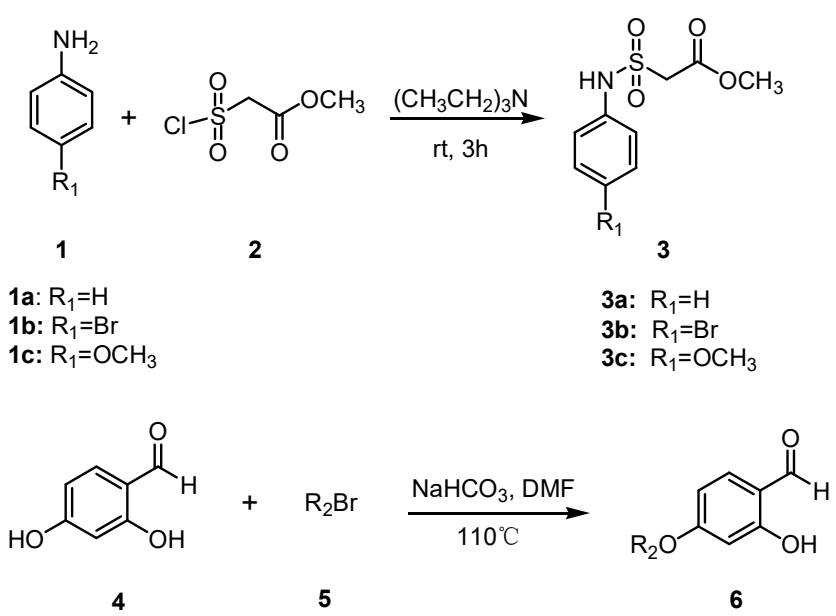

$$
\begin{array}{ll}
\text { 5a: } \mathrm{R}_{2}=\mathrm{CH}_{2} \mathrm{CH}_{3} & \text { 6a: } \mathrm{R}_{2}=\mathrm{CH}_{2} \mathrm{CH}_{3} \\
\text { 5b: } \mathrm{R}_{2}=\mathrm{CH}_{2} \mathrm{CH}_{2} \mathrm{CH}_{3} & \text { 6b: } \mathrm{R}_{2}=\mathrm{CH}_{2} \mathrm{CH}_{2} \mathrm{CH}_{3}
\end{array}
$$<smiles>COC(=O)CS(=O)(=O)Nc1ccccc1</smiles>

3a<smiles>[R20]c1ccc(C=O)c(O)c1</smiles>
6

6a: $\mathrm{R}_{2}=\mathrm{CH}_{2} \mathrm{CH}_{3}$ 6b: $\mathrm{R}_{2}=\mathrm{CH}_{2} \mathrm{CH}_{2} \mathrm{CH}_{3}$<smiles>[R20]c1ccc2cc(S(=O)(=O)Nc3ccccc3)c(=O)oc2c1</smiles>

7

7a: $\mathrm{R}_{2}=\mathrm{CH}_{2} \mathrm{CH}_{3}$ 7b: $\mathrm{R}_{2}=\mathrm{CH}_{2} \mathrm{CH}_{2} \mathrm{CH}_{3}$<smiles>[R]C(=O)CS(=O)(=O)Nc1ccc([R])cc1</smiles>

3

3a: $\mathrm{R}_{1}=\mathrm{H}$

3b: $\mathrm{R}_{1}=\mathrm{Br}$

3c: $\mathrm{R}_{1}=\mathrm{OCH}_{3}$<smiles>[R7]c1ccc(NS(=O)(=O)c2cc3ccc(N(CC)CC)cc3oc2=O)cc1</smiles>

9a: $\mathrm{R}_{1}=\mathrm{H}$

Scheme 1. Synthesis of compounds $7 a-7 b$ and $9 a-9 c$<smiles>CCN(CC)c1ccc(C=O)c(O)c1</smiles>

8

10

11<smiles>[R3]c1ccc(NC(=O)c2cc3ccc(N)cc3oc2=O)cc1</smiles>

11

12a: $\mathrm{R}_{3}=\mathrm{H}$

Scheme 2. Synthesis of compounds 12a-12c. 
Table 1. The structures of coumarin sulfonamides and coumarin amides derivatives.

Compd Structure

Table 2. Inhibition of cancer cells proliferation by compounds $7 a-7 b, 9 a-9 c$ and $\mathbf{1 2 a}-\mathbf{1 2 c}$.

\begin{tabular}{cccc}
\hline \multirow{2}{*}{ Compd } & \multicolumn{3}{c}{ IC $_{\mathbf{5 0}}(\boldsymbol{\mu M})$} \\
\cline { 2 - 4 } & MDA-MB-231 & KB & HCT-116 \\
\hline $\mathbf{7 a}$ & $>100$ & $79.46 \pm 1.62$ & $>100$ \\
$\mathbf{7 b}$ & $>100$ & $20.21 \pm 0.42$ & $>100$ \\
$\mathbf{9 a}$ & $>100$ & $34.94 \pm 2.83$ & $15.51 \pm 1.59$ \\
$\mathbf{9 b}$ & $17.13 \pm 0.68$ & $10.78 \pm 0.13$ & $17.26 \pm 2.00$ \\
$\mathbf{9 c}$ & $9.33 \pm 1.81$ & $13.66 \pm 1.33$ & $>100$ \\
$\mathbf{1 2 a}$ & $13.33 \pm 1.26$ & $>100$ & $>100$ \\
$\mathbf{1 2 b}$ & $11.63 \pm 0.98$ & $14.22 \pm 1.64$ & $>100$ \\
$\mathbf{1 2} \mathbf{c}$ & $17.01 \pm 1.04$ & $97.14 \pm 2.43$ & $>100$ \\
$\mathbf{5 - F u}$ & $8.59 \pm 0.52$ & $94.15 \pm 2.76$ & $15.28 \pm 0.31$ \\
\hline
\end{tabular}

In addition, it was observed that among coumarin sulfonamides $\mathbf{7 a - 7 b}$ and $\mathbf{9 a}-\mathbf{9} \mathbf{c}, 7$ diethylaminocoumarin sulfonamides 9a-9c exhibited higher activity than 7-alkoxycoumarin sulfonamides $\mathbf{7 a}-\mathbf{7 b}$, which implied the diethylamino group at C-7 position improved potency. Coumarin sulfonamides $\mathbf{9 a - 9 c}$ had better cytotoxicity compared to amides derivatives 12a-12c, suggesting the sulfonamide moiety at C-3 position of the coumarin core is favored to the activity. Furthermore, the $\mathrm{IC}_{50}$ values of compounds $\mathbf{9 a}-\mathbf{9 c}$ and $\mathbf{1 2 a}-\mathbf{1 2 c}$ indicated that substituents on the benzene ring in the sulfonamides or amides had little impact on the potency.

\subsection{Inhibition of Wound Healing in MDA-MB-231 Cells by Compound 9c}

The wound healing assay is a classic and common method used to investigate the effect of antitumor drugs on tumor migration. We next assessed the effect of compound 9c on the migration of MDA-MB-231 cells with a wound-healing assay. The results showed that the scratch gaps in compound 9c $(10$ and $20 \mu \mathrm{M})$ treated MDA-MB-231 cells were wider than the control with increased treating time (Figure 2). The cell migration was inhibited, and the wound area was increased compared with the control in a concentrationdependent manner. 


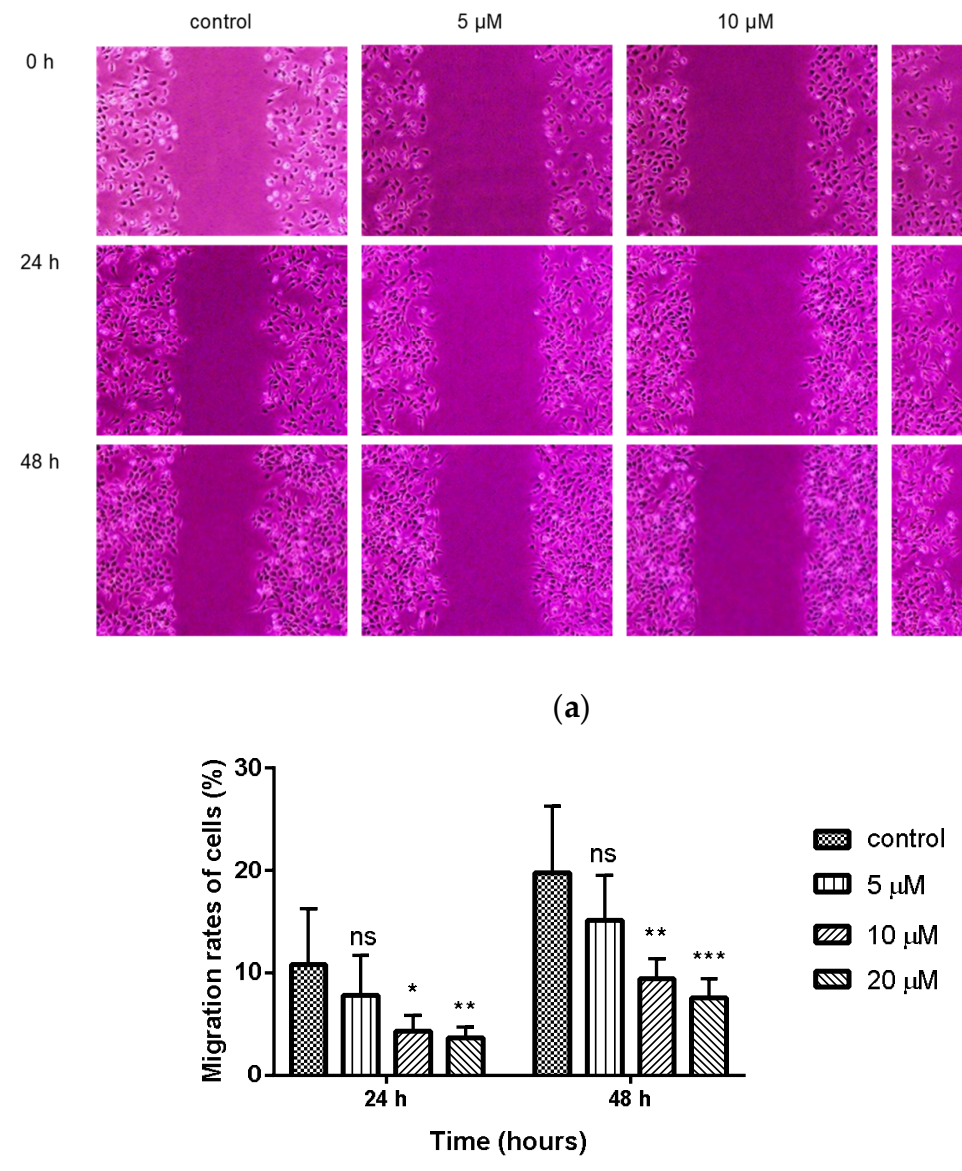

(b)

Figure 2. Compound 9c inhibited wound healing of MDA-MB-231 cells. (a) The wound was captured at different time points $(0,24$, and $48 \mathrm{~h})$. (b) Quantification of the cell scrape results $(n=6)$ by using One-Way ANOVA followed by post-hoc Tukey's test. ${ }^{* * *}(p<0.001),{ }^{* *}(p<0.01),{ }^{*}(p<0.05)$, ns (not significant).

\subsection{Inhibition of Compond $9 \mathrm{c}$ on the Invasion of MDA-MB-231 Cells}

Transwell invasion assay was used to investigate the effect of compound $9 \mathrm{c}$ on the invasion of MDA-MB-231 cells. Treatment of compound $9 \mathbf{c}$ significantly reduced $(p<0.01)$ the number of invaded cells at the concentration of $20 \mu \mathrm{M}$ (Figure 3).

\subsection{Compound 9c Induces Apoptosis in MDA-MB-231 Cells}

To further evaluate whether compound $9 \mathrm{c}$ can induce apoptosis, the Annexin VFITC/PI double-staining assay was applied with flow cytometer. After treatment with compound 9c for $48 \mathrm{~h}$, MDA-MB-231 cells were dyed by Annexin V-FITC and showed green fluorescence, which indicates the early phase of apoptosis. The cells dyed by Annexin V-FITC and PI showed red fluorescence inside with green fluorescence outside, which corresponded to the late phase of apoptosis (Figure 4a). The cells treated with compound 9c $(10 \mu \mathrm{M})$ had stronger fluorescence intensity compared with the control group, which indicated that compound $9 \mathrm{c}$ promoted apoptosis of MDA-MB-231 cells. Meanwhile, as shown in Figure $4 b, c$, when treated with different concentrations of compound $9 c$, the percentages of apoptotic MDA-MB-231 cells increased from 3.85\% in control cells to $7.72 \%$, $20.11 \%, 40.71 \%, 53.50 \%$, and $57.46 \%$, respectively. The results implied that compound $9 \mathrm{c}$ could induce the apoptosis of MDA-MB-231 cells in a concentration-dependent manner. 

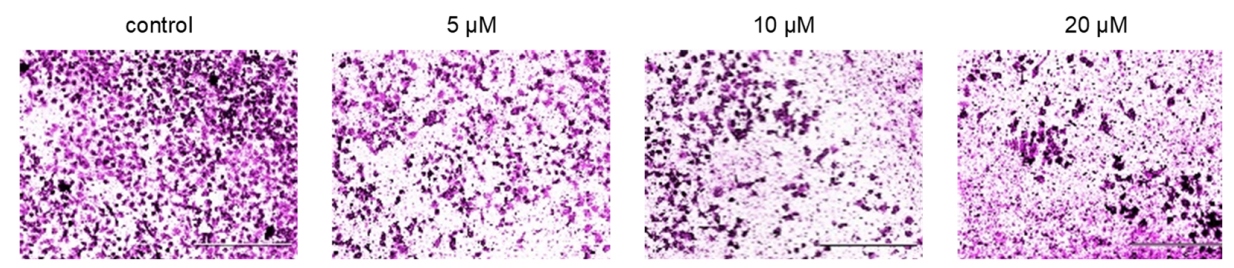

(a)

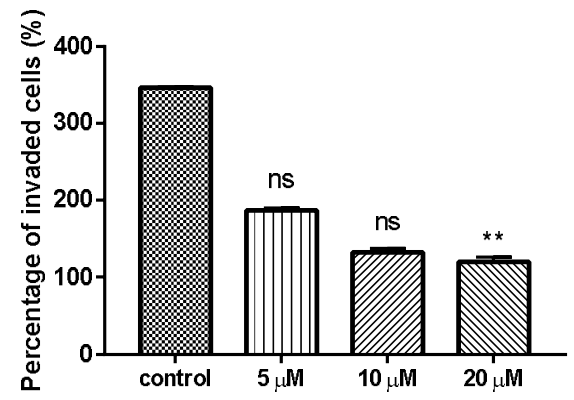

(b)

Figure 3. Compound 9c inhibited invasion of MDA-MB-231 cells. (a) Microscope images of the MDA-MB-231 cells that invaded through the matrigel after exposure to different concentrations of compound 9c for $48 \mathrm{~h}$. Scale bar: $400 \mu \mathrm{m}$. (b) Quantification of the cell invasion results $(n=3)$ by using Kruskal-Wallis test followed by post-hoc Dunn's test. ** $(p<0.01)$, ns (not significant).
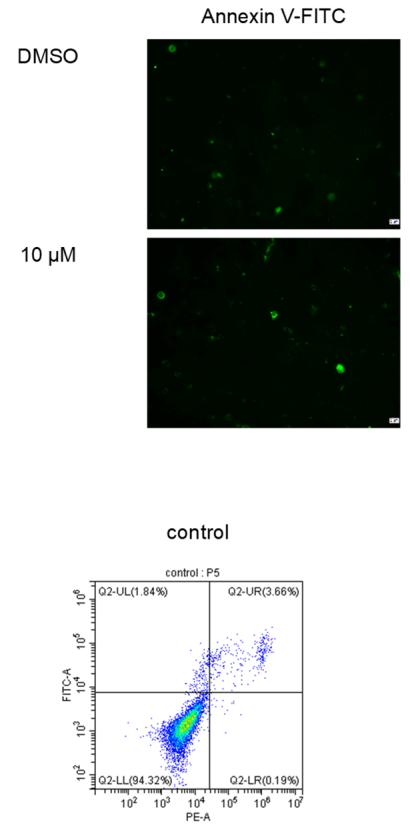

$20 \mu \mathrm{M}$

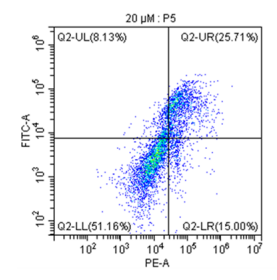

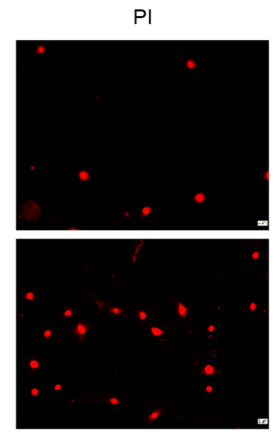

(a)

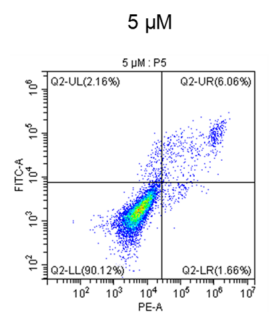

$40 \mu \mathrm{M}$

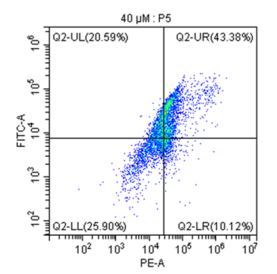

(b)
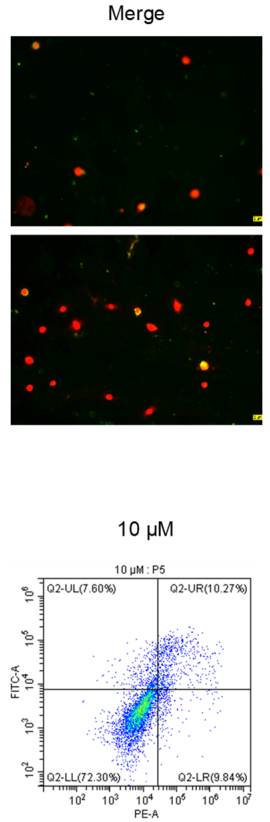

$80 \mu \mathrm{M}$

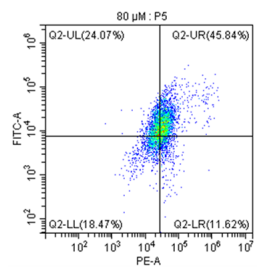

Figure 4. Cont. 


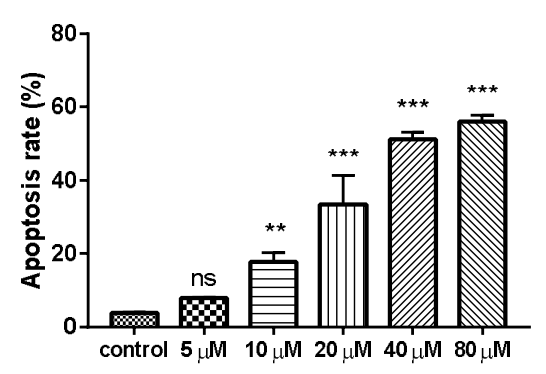

(c)

Figure 4. Compound 9c induced apoptosis of MDA-MB-231 cells. (a) Effect of compound 9c on MDA-MB-231 cells apoptosis morphology. Scale bar: $2 \mu \mathrm{m}$. (b) Dot plot depicting MDA-MB-231 cells treated with different concentrations of compound 9c for $48 \mathrm{~h}$. (c) Quantification of the cell apoptosis results $(n=3)$ by using One-Way ANOVA followed by post-hoc Tukey's test. ${ }^{* *}(p<0.001),{ }^{* *}(p<0.01)$, ns (not significant).

\subsection{Compound 9c Increases ROS Production in MDA-MB-231 Cells}

We utilized the $2^{\prime}, 7^{\prime}$-dichlorofluorescin diacetate (DCFH-DA) fluorescence probe to further evaluate the changes in intracellular ROS level after treating MDA-MB-231 cells with compound 9c. Intracellular ROS can oxidize $2^{\prime}, 7^{\prime}$-dichlorofluorescin (DCFH) into the fluorescent $2^{\prime}, 7^{\prime}$-dichlorofluorescein (DCF) whose intensity is proportional to the amount of intracellular ROS. After these cells were subjected to various doses of compound 9c (10, 20,30 , and $40 \mu \mathrm{M}$ ), the fluorescence intensity increased obviously (Figure 5), revealing that compound 9c induced intracellular ROS production in concentration-dependent manner.
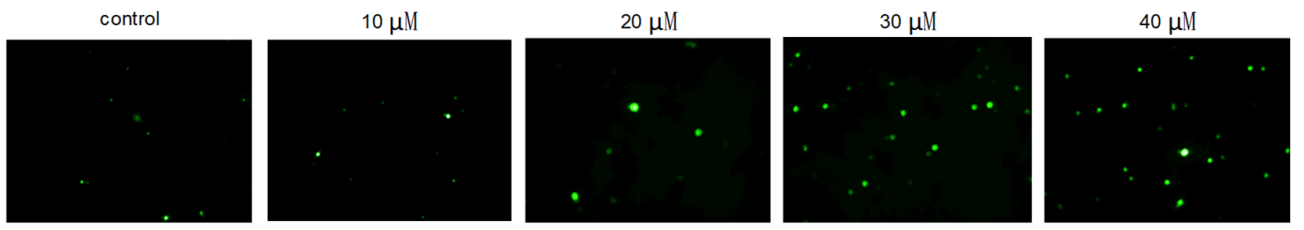

(a)

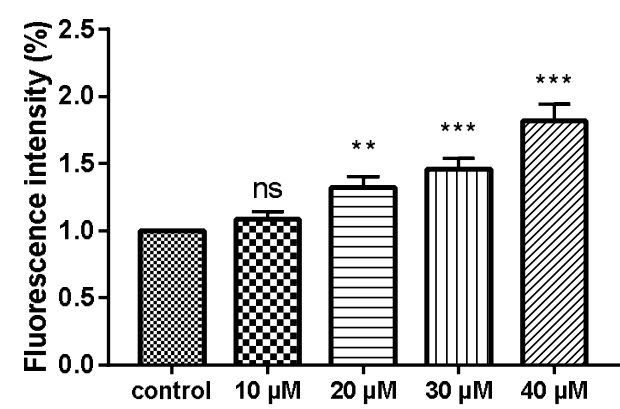

(b)

Figure 5. Compound 9c increased ROS production of MDA-MB-231 cells. (a) MDA-MB-231 cells were treated with different concentrations of compound 9c for $48 \mathrm{~h}$. (b) Quantification of the ROS production $(n=3)$ by using One-Way ANOVA followed by post-hoc Tukey's test. ${ }^{* *}(p<0.001),{ }^{* *}(p<0.01)$, ns (not significant).

\subsection{Western Blot Analysis}

Next, Western blot analysis was applied to understand the molecular mechanism of apoptosis induced by compound 9c. The protein expression levels of caspase-3 and Bcl-2 were detected since caspase- 3 played a crucial role in apoptotic pathways by cleaving a variety of key cellular proteins, and Bcl-2 is the well-known anti-apoptotic marker. After exposure of MDA-MB-231 cells to compound 9c, the expression level of caspase-3 was dramatically increased, while no obvious effect on the expression of Bcl-2 was observed (Figure 6). 


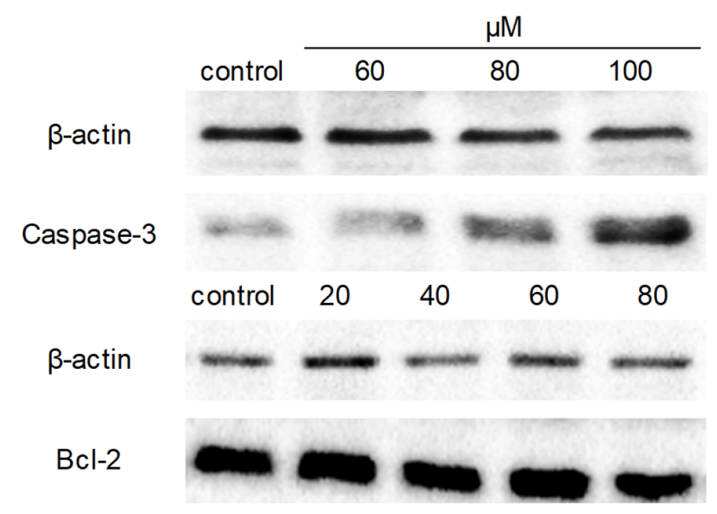

Figure 6. Compound 9c affected caspase-3 and Bcl-2 expression levels of MDA-MB-231 cells. MDAMB-231 cells were seeded in 6-well plates and treated with different concentrations of compound 9c for $48 \mathrm{~h}$. The protein expression levels of caspase- 3 and Bcl-2 were evaluated by western blot, $\beta$-actin served as a loading control.

\section{Discussion}

Coumarins and their derivatives have been regarded as an important family of anticancer lead compounds, which exhibit diverse effects such as anti-proliferation, antiinvasion, anti-metastasis, anti-angiogenesis and inducing apoptosis. The various mechanisms of their anticancer action have been widely explored [22-28], including inhibition of carbonic anhydrase, $\mathrm{PI} 3 \mathrm{~K} / \mathrm{AKT} / \mathrm{mTOR}$ signaling pathway, microtubule polymerization, monocarboxylate transporters, hypoxia-inducible factor-1, acting on apoptosis proteins, inhibiting tumor multidrug resistance, and regulating ROS.

In this study, coumarin sulfonamide $9 \mathrm{c}$ with the best antiproliferative activity against MDA-MB-231 and KB cell lines were obtained by modification of the basic structure of coumarin. The effects of compound $9 \mathrm{c}$ on the migration and invasion of MDA-MB-231 cells have been further investigated since the ability of cancer cells to migrate and invade into the surrounding tissue is the hallmark of tumor metastasis [29]. Treatment using compound $9 \mathrm{c}$ has shown significant reduction in the percentage of migration and invasion of MDA-MB-231 cells in a concentration-dependent manner.

Apoptosis, an immunogenic programmed cell death, eliminates unhealthy, unwanted cells and maintains surrounding tissue [30]. In cancer, evasion of cell death is one of the major mechanisms for abnormal cells to transform themselves into malignant ones [31]. Thus, drugs that can induce apoptosis, specifically in malignant and metastatic cells, would be the most promising cancer treatment candidates. Annexin V-FITC/PI double-staining assay combined with flow cytometry analysis confirmed that compound $9 \mathrm{c}$ induced apoptosis in MDA-MB-231 cells significantly in a concentration-dependent manner. Most antitumor reagents that can induce apoptosis, including many first-line chemotherapy drugs such as cisplatin, are known to provoke oxidative stress by generating excess ROS, which suggests that abnormal ROS generation is closely associated with apoptosis [32]. Our results of ROS assay showed that ROS levels in MDA-MB-231 cells were significantly increased after treatment with compound $9 \mathrm{c}$.

The activation of the key apoptotic protein caspase-3 [33] can cleave regulatory proteins essential for cell survival and maintenance as well as poly (ADP-ribose) polymerase (PARP), which is involved in DNA repair and programmed cell death, thereby promoting apoptosis. Bcl-2 as an anti-apoptotic protein has been shown to enhance cell survival by inhibiting apoptosis and enhance the sensitivity of tumor cells to chemotherapy drugs [34-36]. Western blotting analysis demonstrated that the expression of caspase- 3 was markedly upregulated, whereas little changes in the expression level of Bcl-2 were observed after treating with compound $9 \mathrm{c}$. These results suggested that compound $9 \mathrm{c}$ induced apoptosis by increasing ROS levels and upregulating caspase-3 expression in MDA-MB-231 cancer cells. 
However, the anticancer mechanism of coumarin sulfonamides needs to be further elucidated. Their anticancer potential, security and pharmacokinetic properties in vivo were also left to be investigated. Anyway, this study offers a start point for further elaboration to develop anticancer reagents with coumarin sulfonamide scaffold. More researches which link the anticancer effect, safety, and bioavailability with structure modification are expected to accelerate the development of coumarin derivatives for cancer treatment.

\section{Materials and Methods}

\subsection{Chemical}

\subsubsection{Syntheses}

All melting points were taken on an X-6 microscope melting point instrument (Bjfuka, Beijing, China) and are uncorrected. Infrared spectra were determined with a TENSORII spectrometer (Bruker, Karlsruhe, Germany). NMR spectra were measured using $300 \mathrm{MHz}$ Bruker AV III spectrometers (Bruker, Karlsruhe, Germany) and 400 MHz JNM-ECZ400S/L1 spectrometers (Varian INOVA, Palo Alto, CA, USA) with tetramethylsilane (TMS) as an internal standard. The following abbreviations were used to designate the multiplicities: $\mathrm{s}=$ singlet, $\mathrm{d}=$ doublet, $\mathrm{t}=$ triplet, $\mathrm{q}=$ quartet, $\mathrm{m}=$ multiplet, brs = broad singlet. Coupling constant $(\mathrm{J})$ is reported in Hertz $(\mathrm{Hz})$. HR-MS spectra were obtained on Finnigan LCQ and Micromass Auto Spec Ultima-Tof spectrometer (Thermo, Boston, Massachusetts, USA). Analytic thin-layer chromatography (TLC) was performed on precoated silica gel 60 F254 plates (Qingdao Haiyang, Qingdao, Shandong Province, China) using petroleum ether-ethyl acetate as solvent system. All the chemicals were of analytic grade. The detailed preparation procedures of intermediates, byproducts, and target compounds are described below.

\subsubsection{General Procedure for the Synthesis of Compounds 3a-3c}

Methyl 2-chlorosulfonylacetate $2(500 \mathrm{mg}, 2.90 \mathrm{mmol})$ was added dropwise to a solution of aromatic amines $1(4.35 \mathrm{mmol})$ in $\mathrm{Et}_{3} \mathrm{~N}(10 \mathrm{~mL})$. The reaction mixture was stirred at room temperature for $3 \mathrm{~h}$. After completion of the reaction, a solution of $10 \% \mathrm{HCl}$ was added slowly to the mixture to adjust the $\mathrm{pH}$ to 7 . The mixture was then extracted with DCM $(12 \mathrm{~mL} \times 3)$. The combined organic layer was dried over anhydrous $\mathrm{Na}_{2} \mathrm{SO}_{4}$ and evaporated in a vacuum to give a crude residue which was purified by column chromatography (cyclohexane: ethyl acetate $=15: 1-1: 1$ ) to yield compounds $3 \mathbf{a}-3 \mathbf{c}$. The ${ }^{1} \mathrm{H}-\mathrm{NMR}$ spectra of compounds $3 \mathbf{a}-\mathbf{3 c}$ are in the Supplementary Materials.

Methyl 2-(N-phenylsulfamoyl)acetate (3a) [37] Yellow solid, yield: $76.3 \% .{ }^{1} \mathrm{H}-\mathrm{NMR}$ $\left(300 \mathrm{MHz} \mathrm{CDCl}_{3}\right) \delta 7.42-7.30\left(\mathrm{~m}, 4 \mathrm{H},-\mathrm{C}_{6} \mathrm{H}_{5}\right), 7.29-7.21\left(\mathrm{~m}, 1 \mathrm{H},-\mathrm{C}_{6} \mathrm{H}_{5}\right), 7.05(\mathrm{brs}, 1 \mathrm{H}$, -NH-), 3.96 (s, 2H, - $\left.\mathrm{CH}_{2}-\mathrm{COO}-\right), 3.82$ (s, 3H, -OCH ${ }_{3}$. HR-MS (ESI): calcd for $\mathrm{C}_{9} \mathrm{H}_{12} \mathrm{NO}_{4} \mathrm{~S}$ $[\mathrm{M}+\mathrm{H}]^{+}$230.0487, found 230.0481 .

Methyl 2-(N-(4-bromophenyl)sulfamoyl)acetate (3b) [37]. Yellow solid, yield: $86.2 \% .{ }^{1} \mathrm{H}-$ $\operatorname{NMR}\left(300 \mathrm{MHz}, \mathrm{CDCl}_{3}\right) \delta 7.52-7.46\left(\mathrm{~m}, 2 \mathrm{H},-\mathrm{C}_{6} \mathrm{H}_{5}\right), 7.25-7.18\left(\mathrm{~m}, 2 \mathrm{H},-\mathrm{C}_{6} \mathrm{H}_{5}\right), 3.94(\mathrm{~s}, 2 \mathrm{H}$, $\left.-\mathrm{CH}_{2}-\mathrm{COO}-\right)$, 3.82 (s, 3H, $-\mathrm{OCH}_{3}$ ). HR-MS (ESI): calcd for $\mathrm{C}_{9} \mathrm{H}_{11} \mathrm{BrNO}_{4} \mathrm{~S}[\mathrm{M}+\mathrm{H}]^{+}$307.9592, found 307.9603.

Methyl 2-(N-(4-methoxyphenyl) sulfamoyl) acetate (3c) [37]. Yellow solid powder, yield: 88.2\%. ${ }^{1} \mathrm{H}-\mathrm{NMR}\left(300 \mathrm{MHz}, \mathrm{CDCl}_{3}\right) \delta 7.30-7.25\left(\mathrm{~m}, 2 \mathrm{H},-\mathrm{C}_{6} \mathrm{H}_{5}\right), 6.91-6.86\left(\mathrm{~m}, 2 \mathrm{H},-\mathrm{C}_{6} \mathrm{H}_{5}\right)$, 6.82 (brs, 1H, -NH-), 3.91 (s, 2H, - $\left.\mathrm{CH}_{2}-\mathrm{COO}-\right)$, 3.83 (s, 3H, - $\left.\mathrm{OCH}_{3}\right), 3.80\left(\mathrm{~s}, 3 \mathrm{H},-\mathrm{OCH}_{3}\right)$. HR-MS (ESI): calcd for $\mathrm{C}_{10} \mathrm{H}_{14} \mathrm{NO}_{5} \mathrm{~S}[\mathrm{M}+\mathrm{H}]^{+} 260.0593$, found 260.0602 .

\subsubsection{General Procedure for the Synthesis of Compounds $\mathbf{6 a}-\mathbf{6 b}$}

2,4-dihydroxybenzaldehyde 4 (200 mg, $1.45 \mathrm{mmol}$ ) and $\mathrm{NaHCO}_{3}(240 \mathrm{mg}, 2.89 \mathrm{mmol})$ were dissolved in anhydrous DMF $(2 \mathrm{~mL})$, followed by the addition of the bromide 5 $(1.45 \mathrm{mmol})$. The reaction mixture was stirred at $110^{\circ} \mathrm{C}$. After completion of the reaction, the reaction mixture was diluted with DCM $(20 \mathrm{~mL})$ and washed with water $(10 \mathrm{~mL})$ and saturated brine $(10 \mathrm{~mL})$. The organic layer was dried over anhydrous $\mathrm{Na}_{2} \mathrm{SO}_{4}$ and evaporated in a vacuum to give a crude residue which was purified by column chromatography 
(cyclohexane: ethyl acetate $=200: 1)$ to yield compounds $\mathbf{6 a}-\mathbf{6} \mathbf{b}$. The ${ }^{1} \mathrm{H}-\mathrm{NMR}$ spectra of compounds $\mathbf{6 a}-\mathbf{6 b}$ are in the Supplementary Materials.

4-Ethoxy-2-hydroxybenzaldehyde (6a) [38]. Light yellow liquid, yield: $51.2 \% .{ }^{1} \mathrm{H}-\mathrm{NMR}$ $\left(300 \mathrm{MHz}, \mathrm{CDCl}_{3}\right) \delta 11.48(\mathrm{~s}, 1 \mathrm{H},-\mathrm{CHO}), 9.70(\mathrm{~s}, 1 \mathrm{H},-\mathrm{OH}), 7.41\left(\mathrm{~d}, J=8.7 \mathrm{~Hz}, 1 \mathrm{H},-\mathrm{C}_{6} \mathrm{H}_{5}\right)$, $6.52\left(\mathrm{dd}, J=8.7,1.8 \mathrm{~Hz}, 1 \mathrm{H},-\mathrm{C}_{6} \mathrm{H}_{5}\right), 6.40\left(\mathrm{~d}, J=2.4 \mathrm{~Hz}, 1 \mathrm{H},-\mathrm{C}_{6} \mathrm{H}_{5}\right), 4.08(\mathrm{q}, J=7.0 \mathrm{~Hz}, 2 \mathrm{H}$, $\left.-\mathrm{OCH}_{2} \mathrm{CH}_{3}\right), 1.43\left(\mathrm{~d}, J=7.2 \mathrm{~Hz}, 3 \mathrm{H},-\mathrm{OCH}_{2} \mathrm{CH}_{3}\right)$. HR-MS (ESI): calcd for $\mathrm{C}_{9} \mathrm{H}_{11} \mathrm{O}_{3}[\mathrm{M}+\mathrm{H}]^{+}$ 167.0708, found 167.0704.

2-hydroxy-4-propoxybenzaldehyde (6b) [38] Light yellow liquid, yield: 57\%. ${ }^{1} \mathrm{H}-\mathrm{NMR}$ $\left(300 \mathrm{MHz}, \mathrm{CDCl}_{3}\right) \delta 11.48(\mathrm{~s}, 1 \mathrm{H},-\mathrm{CHO}), 9.70(\mathrm{~d}, J=0.4 \mathrm{~Hz}, 1 \mathrm{H},-\mathrm{OH}), 7.41(\mathrm{~d}, J=8.7 \mathrm{~Hz}$, $\left.1 \mathrm{H},-\mathrm{C}_{6} \mathrm{H}_{5}\right), 6.55-6.51\left(\mathrm{~m}, 1 \mathrm{H},-\mathrm{C}_{6} \mathrm{H}_{5}\right), 6.41\left(\mathrm{~d}, J=2.2 \mathrm{~Hz}, 1 \mathrm{H},-\mathrm{C}_{6} \mathrm{H}_{5}\right), 3.97(\mathrm{t}, J=7.2 \mathrm{~Hz}$, $\left.2 \mathrm{H},-\mathrm{OCH}_{2} \mathrm{CH}_{2} \mathrm{CH}_{3}\right), 1.84\left(\mathrm{~m}, 2 \mathrm{H},-\mathrm{OCH}_{2} \mathrm{CH}_{2} \mathrm{CH}_{3}\right), 1.04\left(\mathrm{t}, J=7.0 \mathrm{~Hz}, 3 \mathrm{H},-\mathrm{OCH}_{2} \mathrm{CH}_{2} \mathrm{CH}_{3}\right)$. HR-MS (ESI): calcd for $\mathrm{C}_{10} \mathrm{H}_{13} \mathrm{O}_{3}[\mathrm{M}+\mathrm{H}]^{+} 181.0865$, found 181.0862 .

\subsubsection{General Procedure for the Synthesis of Compounds $7 \mathbf{a}-7 \mathbf{b}$}

Under a $\mathrm{N}_{2}$ atmosphere, compound $3 \mathrm{a}(0.388 \mathrm{mmol}, 89 \mathrm{mg})$ and compound 6 ( $\left.0.466 \mathrm{mmol}\right)$ were dissolved in anhydrous ethanol $(2 \mathrm{~mL})$, and piperidine $(1.4 \mathrm{mmol}, 0.1 \mathrm{~mL})$ was added dropwise. The resulting mixture was stirred at $87^{\circ} \mathrm{C}$. After completion of the reaction, the solvent was removed under reduced pressure and water $(10 \mathrm{~mL})$ was added to the residue and then extracted with DCM $(10 \mathrm{~mL} \times 3)$. The combined organic layers were dried over anhydrous $\mathrm{Na}_{2} \mathrm{SO}_{4}$ and evaporated in a vacuum to give a crude residue which was purified by column chromatography (cyclohexane: ethyl acetate $=100: 1-5: 1$ ) to yield compounds $7 \mathbf{a}-7 \mathbf{b}$. The NMR spectra of compounds $7 \mathbf{a}-7 \mathbf{b}$ are in the Supplementary Materials.

7-Ethoxy-2-oxo-N-phenyl-2H-chromene-3-sulfonamide (7a). Light yellow solid, yield: 50.2\%. mp: 204-206 ${ }^{\circ}$; IR (KBr) $v_{\max }\left(\mathrm{cm}^{-1}\right) 3288,1722,1595,1494 ;{ }^{1} \mathrm{H}-\mathrm{NMR}(300 \mathrm{MHz}$, $\left.\mathrm{CDCl}_{3}\right) \delta 8.35\left(\mathrm{~s}, 1 \mathrm{H},-\mathrm{C}_{6} \mathrm{H}_{5}\right), 7.45\left(\mathrm{~d}, J=8.7 \mathrm{~Hz}, 1 \mathrm{H},-\mathrm{C}_{6} \mathrm{H}_{5}\right), 7.30(\mathrm{~d}, J=9.2,7.2 \mathrm{~Hz}$, $\left.4 \mathrm{H},-\mathrm{C}_{6} \mathrm{H}_{5}\right), 7.13\left(\mathrm{~d}, J=6.6 \mathrm{~Hz}, 1 \mathrm{H},-\mathrm{C}_{6} \mathrm{H}_{5}\right), 6.88\left(\mathrm{~d}, J=7.7 \mathrm{~Hz}, 1 \mathrm{H},-\mathrm{C}_{6} \mathrm{H}_{5}\right), 6.80(\mathrm{~s}, 1 \mathrm{H}$, $\left.-\mathrm{C}_{6} \mathrm{H}_{5}\right), 4.27\left(\mathrm{q}, J=7.2 \mathrm{~Hz}, 2 \mathrm{H},-\mathrm{OCH}_{2} \mathrm{CH}_{3}\right), 1.46\left(\mathrm{t}, J=7.2 \mathrm{~Hz}, 3 \mathrm{H},-\mathrm{OCH}_{2} \mathrm{CH}_{3}\right) .{ }^{13} \mathrm{C}-\mathrm{NMR}$ (75 MHz, DMSO-d 6 ) $\delta 164.50$ (-COO-), $156.85(-\mathrm{CH}=\mathrm{C}), 155.11(-\mathrm{CH}=\mathrm{C}), 149.06(-\mathrm{CH}=\mathrm{C})$, $137.61(-\mathrm{CH}=\mathrm{C}), 132.19(-\mathrm{CH}=\mathrm{C}), 129.28(-\mathrm{CH}=\mathrm{C}), 124.30(-\mathrm{CH}=\mathrm{C}), 120.75(-\mathrm{CH}=\mathrm{C}), 120.20$ $(-\mathrm{CH}=\mathrm{C}), 114.06(-\mathrm{CH}=\mathrm{C}), 110.55(-\mathrm{CH}=\mathrm{C}), 100.94(-\mathrm{CH}=\mathrm{C}), 64.60\left(-\mathrm{OCH}_{2} \mathrm{CH}_{3}\right), 14.28$ $\left(-\mathrm{OCH}_{2} \mathrm{CH}_{3}\right)$. HR-MS (ESI): calcd for $\mathrm{C}_{17} \mathrm{H}_{16} \mathrm{NO}_{5} \mathrm{~S}[\mathrm{M}+\mathrm{H}]^{+} 346.0749$, found 346.0755.

7-propoxy-2-oxo-N-phenyl-2H-chromene-3-sulfonamide (7b). Light yellow solid, yield: $66.5 \%$. mp: 200-202 ${ }^{\circ} \mathrm{C}$; IR (KBr) $v_{\max }\left(\mathrm{cm}^{-1}\right) 3314,1717,1615,1546 ;{ }^{1} \mathrm{H}-\mathrm{NMR}\left(300 \mathrm{MHz}, \mathrm{CDCl}_{3}\right) \delta$ $8.34\left(\mathrm{~s}, 1 \mathrm{H},-\mathrm{C}_{6} \mathrm{H}_{5}\right), 7.45\left(\mathrm{~d}, J=8.8 \mathrm{~Hz}, 1 \mathrm{H},-\mathrm{C}_{6} \mathrm{H}_{5}\right), 7.24\left(\mathrm{dd}, J=9.4,7.6 \mathrm{~Hz}, 4 \mathrm{H},-\mathrm{C}_{6} \mathrm{H}_{5}\right), 7.13(\mathrm{t}$, $\left.J=7.4 \mathrm{~Hz}, 1 \mathrm{H},-\mathrm{C}_{6} \mathrm{H}_{5}\right), 6.90\left(\mathrm{~d}, J=8.7 \mathrm{~Hz}, 1 \mathrm{H},-\mathrm{C}_{6} \mathrm{H}_{5}\right), 6.81\left(\mathrm{~s}, 1 \mathrm{H},-\mathrm{C}_{6} \mathrm{H}_{5}\right), 4.00(\mathrm{t}, J=6.5 \mathrm{~Hz}$, $\left.2 \mathrm{H},-\mathrm{OCH}_{2} \mathrm{CH}_{2} \mathrm{CH}_{3}\right), 1.85\left(\mathrm{dd}, J=14.0,7.0 \mathrm{~Hz}, 2 \mathrm{H},-\mathrm{OCH}_{2} \mathrm{CH}_{2} \mathrm{CH}_{3}\right), 1.05(\mathrm{t}, J=7.4 \mathrm{~Hz}, 3 \mathrm{H}$, $\left.-\mathrm{OCH}_{2} \mathrm{CH}_{2} \mathrm{CH}_{3}\right) \cdot{ }^{13} \mathrm{C}-\mathrm{NMR}\left(75 \mathrm{MHz}, \mathrm{DMSO}-d_{6}\right) \delta 164.62$ (-COO-), 156.81 (-CH=C), 155.09 $(-\mathrm{CH}=\mathrm{C}), 149.03(-\mathrm{CH}=\mathrm{C}), 137.17(-\mathrm{CH}=\mathrm{C}), 132.14(-\mathrm{CH}=\mathrm{C}), 129.13(-\mathrm{CH}=\mathrm{C}), 124.05(-\mathrm{CH}=\mathrm{C})$, $120.75(-\mathrm{CH}=\mathrm{C}), 119.92(-\mathrm{CH}=\mathrm{C}), 113.98$ ( $-\mathrm{CH}=\mathrm{C}), 110.52(-\mathrm{CH}=\mathrm{C}), 100.91(-\mathrm{CH}=\mathrm{C}), 70.19$ (-OCH $\left.\mathrm{CH}_{2} \mathrm{CH}_{3}\right), 21.70\left(-\mathrm{OCH}_{2} \mathrm{CH}_{2} \mathrm{CH}_{3}\right), 10.21\left(-\mathrm{OCH}_{2} \mathrm{CH}_{2} \mathrm{CH}_{3}\right)$. HR-MS (ESI): calcd for $\mathrm{C}_{18} \mathrm{H}_{18} \mathrm{NO}_{5} \mathrm{~S}[\mathrm{M}+\mathrm{H}]^{+}$360.0906, found 360.0897 .

\subsubsection{General Procedure for the Synthesis of Compounds 9a-9c}

Under a $\mathrm{N}_{2}$ atmosphere, compound 3 (1 mmol) and 4-(diethylamino) salicylaldehyde $8(1.2 \mathrm{mmol}, 232 \mathrm{mg})$ were dissolved in anhydrous ethanol and piperidine $(1.4 \mathrm{mmol}$, $0.1 \mathrm{~mL}$ ) was then added dropwise. The resulting mixture was heated under reflux with stirring for $30 \mathrm{~min}$. The solvent was removed under reduced pressure and water $(10 \mathrm{~mL})$ was added to the residue, and then extracted with DCM $(10 \mathrm{~mL} \times 3)$. The combined organic layers were dried over anhydrous $\mathrm{Na}_{2} \mathrm{SO}_{4}$ and evaporated in a vacuum to give a crude residue which was purified by column chromatography (cyclohexane: ethyl acetate $=10: 1$ ) to yield compounds $\mathbf{9 a}-\mathbf{9} \mathbf{c}$. The NMR spectra of compounds $\mathbf{9 a}-\mathbf{9} \mathbf{c}$ are in the Supplementary Materials.

7-(Diethylamino)-2-oxo-N-phenyl-2H-chromene-3-sulfonamide (9a). White solid, yield: 61.3\%. mp: $211-213{ }^{\circ} \mathrm{C}$. IR (KBr) $v_{\max }\left(\mathrm{cm}^{-1}\right) 3273,2974,1708,1614 ;{ }^{1} \mathrm{H}-\mathrm{NMR}(300 \mathrm{MHz}$, 
DMSO-d 6 ) $\delta 10.19(\mathrm{~s}, 1 \mathrm{H},-\mathrm{NH}-), 8.55\left(\mathrm{~s}, 1 \mathrm{H},-\mathrm{C}_{6} \mathrm{H}_{5}\right), 7.64\left(\mathrm{~d}, J=9.1 \mathrm{~Hz}, 1 \mathrm{H},-\mathrm{C}_{6} \mathrm{H}_{5}\right)$, 7.29-7.08 (m, 4H, $\left.-\mathrm{C}_{6} \mathrm{H}_{5}\right), 6.98\left(\mathrm{t}, J=7.2 \mathrm{~Hz}, 1 \mathrm{H},-\mathrm{C}_{6} \mathrm{H}_{5}\right), 6.76(\mathrm{dd}, J=9.1,2.3 \mathrm{~Hz}, 1 \mathrm{H}$, $\left.-\mathrm{C}_{6} \mathrm{H}_{5}\right), 6.51\left(\mathrm{~d}, \mathrm{~J}=2.1 \mathrm{~Hz}, 1 \mathrm{H},-\mathrm{C}_{6} \mathrm{H}_{5}\right), 3.44\left(\mathrm{q}, \mathrm{J}=6.9 \mathrm{~Hz}, 4 \mathrm{H},-\mathrm{NCH}_{2} \mathrm{CH}_{3}\right), 1.09(\mathrm{t}, J=7.0$ $\left.\mathrm{Hz}, 6 \mathrm{H},-\mathrm{NCH}_{2} \mathrm{CH}_{3}\right) .{ }^{13} \mathrm{C}-\mathrm{NMR}\left(75 \mathrm{MHz}, \mathrm{DMSO}-d_{6}\right) \delta 157.73$ (-COO-), 155.75 (-CH=C), 152.99 (-CH=C), $148.47(-\mathrm{CH}=\mathrm{C}), 137.62$ (-CH=C), 132.05 (-CH=C), 129.04 (-CH=C), 123.68 $(-\mathrm{CH}=\mathrm{C}), 119.59(-\mathrm{CH}=\mathrm{C}), 114.85(-\mathrm{CH}=\mathrm{C}), 110.13(-\mathrm{CH}=\mathrm{C}), 105.96(-\mathrm{CH}=\mathrm{C}), 96.01(-\mathrm{CH}=\mathrm{C})$, $44.41\left(-\mathrm{NCH}_{2} \mathrm{CH}_{3}\right), 12.23\left(-\mathrm{NCH}_{2} \mathrm{CH}_{3}\right)$. HR-MS (ESI): calcd for $\mathrm{C}_{19} \mathrm{H}_{21} \mathrm{~N}_{2} \mathrm{O}_{4} \mathrm{~S}[\mathrm{M}+\mathrm{H}]^{+}$ 373.1222 , found 373.1229 .

N-(4-bromophenyl)-7-(diethylamino)-2-oxo-2H-chromene-3-sulfonamide (9b). White solid, yield: $59.2 \%$. mp: $192-194^{\circ} \mathrm{C}$. IR (KBr) $v_{\max }\left(\mathrm{cm}^{-1}\right)$ 3267, 2976, 1711, 1613; ${ }^{1} \mathrm{H}-\mathrm{NMR}$ $\left(300 \mathrm{MHz}, \mathrm{CDCl}_{3}\right) \delta 8.17\left(\mathrm{~s}, 1 \mathrm{H},-\mathrm{C}_{6} \mathrm{H}_{5}\right), 7.38-7.33\left(\mathrm{~m}, 2 \mathrm{H},-\mathrm{C}_{6} \mathrm{H}_{5}\right), 7.30(\mathrm{~d}, J=9.0 \mathrm{~Hz}, 1 \mathrm{H}$, $\left.-\mathrm{C}_{6} \mathrm{H}_{5}\right), 7.14-7.07\left(\mathrm{~m}, 2 \mathrm{H},-\mathrm{C}_{6} \mathrm{H}_{5}\right), 6.61\left(\mathrm{dd}, J=9.0,2.5 \mathrm{~Hz}, 1 \mathrm{H},-\mathrm{C}_{6} \mathrm{H}_{5}\right), 6.44(\mathrm{~d}, J=2.3 \mathrm{~Hz}$, $\left.1 \mathrm{H},-\mathrm{C}_{6} \mathrm{H}_{5}\right), 3.44\left(\mathrm{q}, J=7.1 \mathrm{~Hz}, 4 \mathrm{H},-\mathrm{NCH}_{2} \mathrm{CH}_{3}\right), 1.22\left(\mathrm{t}, J=7.1 \mathrm{~Hz}, 6 \mathrm{H},-\mathrm{NCH}_{2} \mathrm{CH}_{3}\right)$. ${ }^{13} \mathrm{C}-\mathrm{NMR}\left(75 \mathrm{MHz}, \mathrm{DMSO}-d_{6}\right) \delta 157.73$ (-COO-), 155.75 (-CH=C), 152.99 (-CH=C), 148.47 $(-\mathrm{CH}=\mathrm{C}), 137.62(-\mathrm{CH}=\mathrm{C}), 132.05(-\mathrm{CH}=\mathrm{C}), 129.04(-\mathrm{CH}=\mathrm{C}), 123.68(-\mathrm{CH}=\mathrm{C}), 119.59(-\mathrm{CH}=\mathrm{C})$, $114.85(-\mathrm{CH}=\mathrm{C}), 110.13(-\mathrm{CH}=\mathrm{C}), 105.96(-\mathrm{CH}=\mathrm{C}), 96.01(-\mathrm{CH}=\mathrm{C}), 44.41\left(-\mathrm{NCH}_{2} \mathrm{CH}_{3}\right), 12.23$ $\left(-\mathrm{NCH}_{2} \mathrm{CH}_{3}\right)$. HR-MS (ESI): calcd for $\mathrm{C}_{19} \mathrm{H}_{20} \mathrm{BrN}_{2} \mathrm{O}_{4} \mathrm{~S}[\mathrm{M}+\mathrm{H}]^{+} 451.0327$; found: 451.0334 .

7-(Diethylamino)-N-(4-methoxyphenyl)-2-oxo-2H-chromene-3-sulfonamide (9c). White solid,

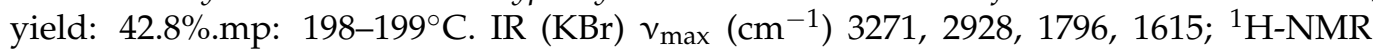
$\left(300 \mathrm{MHz}, \mathrm{CDCl}_{3}\right) \delta 8.12\left(\mathrm{~s}, 1 \mathrm{H},-\mathrm{C}_{6} \mathrm{H}_{5}\right), 7.27\left(\mathrm{~d}, J=6.6 \mathrm{~Hz}, 1 \mathrm{H},-\mathrm{C}_{6} \mathrm{H}_{5}\right), 7.16(\mathrm{~d}, J=8.8 \mathrm{~Hz}$, $\left.2 \mathrm{H},-\mathrm{C}_{6} \mathrm{H}_{5}\right), 6.76\left(\mathrm{~d}, J=8.8 \mathrm{~Hz}, 2 \mathrm{H},-\mathrm{C}_{6} \mathrm{H}_{5}\right), 6.60\left(\mathrm{dd}, J=9.0,2.0 \mathrm{~Hz}, 1 \mathrm{H},-\mathrm{C}_{6} \mathrm{H}_{5}\right), 6.46(\mathrm{~s}$, $\left.1 \mathrm{H},-\mathrm{C}_{6} \mathrm{H}_{5}\right), 3.72\left(\mathrm{~s}, 3 \mathrm{H},-\mathrm{OCH}_{3}\right), 3.42\left(\mathrm{q}, J=7.1 \mathrm{~Hz}, 4 \mathrm{H},-\mathrm{NCH}_{2} \mathrm{CH}_{3}\right), 1.22(\mathrm{~d}, J=7.1 \mathrm{~Hz}$, $\left.6 \mathrm{H},-\mathrm{NCH}_{2} \mathrm{CH}_{3}\right) .{ }^{13} \mathrm{C}-\mathrm{NMR}\left(75 \mathrm{MHz}, \mathrm{DMSO}-d_{6}\right) \delta 157.70$ (-COO-), 156.37 (-CH=C), 155.92 $(-\mathrm{CH}=\mathrm{C}), 152.90(-\mathrm{CH}=\mathrm{C}), 148.20(-\mathrm{CH}=\mathrm{C}), 131.95(-\mathrm{CH}=\mathrm{C}), 129.97(-\mathrm{CH}=\mathrm{C}), 123.14(-\mathrm{CH}=\mathrm{C})$, $115.03(-\mathrm{CH}=\mathrm{C}), 114.22(-\mathrm{CH}=\mathrm{C}), 110.0$ (-CH=C)9, $105.99(-\mathrm{CH}=\mathrm{C}), 96.03$ (-CH=C), 55.09 $\left(-\mathrm{OCH}_{3}\right), 44.40\left(-\mathrm{NCH}_{2} \mathrm{CH}_{3}\right), 12.25\left(-\mathrm{NCH}_{2} \mathrm{CH}_{3}\right)$. HR-MS (ESI): calcd for $\mathrm{C}_{20} \mathrm{H}_{23} \mathrm{~N}_{2} \mathrm{O}_{5} \mathrm{~S}$ [M $+\mathrm{H}]^{+}$: 403.1328; found: 403.1333 .

\subsubsection{Synthesis of Compound $\mathbf{1 1}$}

Under a $\mathrm{N}_{2}$ atmosphere, 4-(diethylamino) salicylaldehyde 8 (1 mmol, $\left.193 \mathrm{mg}\right)$ and diethyl malonate 10 (2 mmol, $320 \mathrm{mg})$ were dissolved in anhydrous ethanol (10 $\mathrm{mL})$ and piperidine $(1.4 \mathrm{mmol}, 0.1 \mathrm{~mL})$ was added dropwise. The reaction mixture was stirred at room temperature for $3 \mathrm{~h} .10 \% \mathrm{HCl}$ was then added into the reaction mixture to adjust the $\mathrm{pH}$ to 8 . The mixture was then extracted with ethyl acetate $(10 \mathrm{~mL} \times 3)$. The combined organic layer was dried over anhydrous $\mathrm{Na}_{2} \mathrm{SO}_{4}$ and evaporated in a vacuum to give a crude residue which was purified by column chromatography (petroleum ether: ethyl acetate $=8: 1$ ) to yield compound 11. The NMR spectra of compound $\mathbf{1 1}$ are in the Supplementary Materials.

Ethyl 7-(diethylamino)-2-oxo-2H-chromene-3-carboxylate (11) [39]. Yellow solid; yield $75 \% .{ }^{1} \mathrm{H}-\mathrm{NMR}\left(400 \mathrm{MHz}, \mathrm{CDCl}_{3}\right) \delta 8.40\left(\mathrm{~s}, 1 \mathrm{H},-\mathrm{C}_{6} \mathrm{H}_{5}\right), 7.33\left(\mathrm{~d}, J=8.9 \mathrm{~Hz}, 1 \mathrm{H},-\mathrm{C}_{6} \mathrm{H}_{5}\right)$, $6.58\left(\mathrm{dd}, J=8.9,2.4 \mathrm{~Hz}, 1 \mathrm{H},-\mathrm{C}_{6} \mathrm{H}_{5}\right), 6.43\left(\mathrm{~d}, J=2.3 \mathrm{~Hz}, 1 \mathrm{H},-\mathrm{C}_{6} \mathrm{H}_{5}\right), 4.34(\mathrm{q}, J=7.1 \mathrm{~Hz}, 2 \mathrm{H}$, $\left.-\mathrm{OCH}_{2} \mathrm{CH}_{3}\right), 3.42\left(\mathrm{q}, \mathrm{J}=7.1 \mathrm{~Hz}, 4 \mathrm{H},-\mathrm{NCH}_{2} \mathrm{CH}_{3}\right), 1.37\left(\mathrm{t}, \mathrm{J}=7.1 \mathrm{~Hz}, 3 \mathrm{H},-\mathrm{OCH}_{2} \mathrm{CH}_{3}\right), 1.21(\mathrm{t}$, $\left.J=7.1 \mathrm{~Hz}, 6 \mathrm{H},-\mathrm{NCH}_{2} \mathrm{CH}_{3}\right) .{ }^{13} \mathrm{C}-\mathrm{NMR}\left(100 \mathrm{MHz} \mathrm{CDCl}_{3}\right) \delta 164.37$ (-COO-), 158.54 (-COO-), $152.96(-\mathrm{CH}=\mathrm{C}), 149.33(-\mathrm{CH}=\mathrm{C}), 131.14(-\mathrm{CH}=\mathrm{C}), 109.62(-\mathrm{CH}=\mathrm{C}), 108.97$ (-CH=C), 107.76 $(-\mathrm{CH}=\mathrm{C}), 96.78(-\mathrm{CH}=\mathrm{C}), 61.25\left(-\mathrm{OCH}_{2} \mathrm{CH}_{3}\right), 45.19\left(-\mathrm{NCH}_{2} \mathrm{CH}_{3}\right), 14.49\left(-\mathrm{OCH}_{2} \mathrm{CH}_{3}\right), 12.52$ $\left(-\mathrm{NCH}_{2} \mathrm{CH}_{3}\right)$. HR-MS (ESI): calcd for $\mathrm{C}_{16} \mathrm{H}_{20} \mathrm{NO}_{4}[\mathrm{M}+\mathrm{H}]^{+} 290.1392$, found 290.1386.

\subsubsection{General Procedure for the Synthesis of Compounds 12a-12c}

Compound 11 (1 mmol, $289 \mathrm{mg})$ and aromatic amines 1 (1.2 mmol) were dissolved in ethanol $(10 \mathrm{~mL})$. The reaction mixture was heated under reflux. After completion of the reaction, the solvent was evaporated in a vacuum followed by the addition of water $(10 \mathrm{~mL})$ and $10 \% \mathrm{HCl}$ to adjust the $\mathrm{pH}$ to 8 . The mixture was then extracted with ethyl acetate $(20 \mathrm{~mL} \times 3)$. The combined organic layer was dried over anhydrous $\mathrm{Na}_{2} \mathrm{SO}_{4}$ and evaporated in a vacuum to give a crude residue which was purified by column 
chromatography (petroleum ether: ethyl acetate $=5: 1-1: 1$ ) to yield compounds 12a-12c. The NMR spectra of compounds 12a-12c are in the Supplementary Materials.

7-(diethylamino)-2-oxo-N-phenyl-2H-chromene-3-carboxamide (12a). Yellow solid; yield 60\%; mp: $156.1-160.0{ }^{\circ} \mathrm{C}$. IR (KBr) $v_{\max }\left(\mathrm{cm}^{-1}\right) 3125,1699,1605 .{ }^{1} \mathrm{H}-\mathrm{NMR}(400 \mathrm{MHz}$, $\left.\mathrm{CDCl}_{3}\right) \delta 10.87(\mathrm{~s}, 1 \mathrm{H},-\mathrm{NH}-), 8.80\left(\mathrm{~s}, 1 \mathrm{H},-\mathrm{C}_{6} \mathrm{H}_{5}\right), 7.74\left(\mathrm{dd}, J=8.5,0.9 \mathrm{~Hz}, 2 \mathrm{H},-\mathrm{C}_{6} \mathrm{H}_{5}\right)$, $7.47\left(\mathrm{~d}, J=9.0 \mathrm{~Hz}, 1 \mathrm{H},-\mathrm{C}_{6} \mathrm{H}_{5}\right), 7.33-7.38\left(\mathrm{~m}, 2 \mathrm{H},-\mathrm{C}_{6} \mathrm{H}_{5}\right), 7.12\left(\mathrm{t}, J=7.4 \mathrm{~Hz}, 1 \mathrm{H},-\mathrm{C}_{6} \mathrm{H}_{5}\right)$, $6.67\left(\mathrm{dd}, J=9.0,2.5 \mathrm{~Hz}, 1 \mathrm{H},-\mathrm{C}_{6} \mathrm{H}_{5}\right), 6.53\left(\mathrm{~d}, J=2.4 \mathrm{~Hz}, 1 \mathrm{H},-\mathrm{C}_{6} \mathrm{H}_{5}\right), 3.47(\mathrm{q}, J=7.2 \mathrm{~Hz}$, $\left.4 \mathrm{H},-\mathrm{NCH}_{2} \mathrm{CH}_{3}\right), 1.25\left(\mathrm{t}, J=7.2 \mathrm{~Hz}, 6 \mathrm{H},-\mathrm{NCH}_{2} \mathrm{CH}_{3}\right) .{ }^{13} \mathrm{C}-\mathrm{NMR}\left(100 \mathrm{MHz}, \mathrm{CDCl}_{3}\right)$ $\delta 163.20$ (-COO-), 161.21 (-CONH-), 157.86 (-CH=C), 152.89 (-CH=C), 148.59 (-CH=C), $138.43(-\mathrm{CH}=\mathrm{C}), 131.42(-\mathrm{CH}=\mathrm{C}), 129.04$ (-CH=C), 124.20 (-CH=C), 120.46 (-CH=C), 110.27 $(-\mathrm{CH}=\mathrm{C}), 108.66(-\mathrm{CH}=\mathrm{C}), 96.68(-\mathrm{CH}=\mathrm{C}), 45.26\left(-\mathrm{NCH}_{2} \mathrm{CH}_{3}\right), 12.55\left(-\mathrm{NCH}_{2} \mathrm{CH}_{3}\right) . \mathrm{HR}-\mathrm{MS}$ (ESI): calcd for $\mathrm{C}_{20} \mathrm{H}_{21} \mathrm{~N}_{2} \mathrm{O}_{3}[\mathrm{M}+\mathrm{H}]^{+}$: 337.1552; found: 337.1561.

$\mathrm{N}$-(4-bromophenyl)-7-(diethylamino)-2-oxo-2H-chromene-3-carboxamide (12b). Yellow solid; yield 59\%; mp: $231.5-235.6{ }^{\circ} \mathrm{C}$. IR (KBr) $v_{\max }\left(\mathrm{cm}^{-1}\right) 3431,1685,1617 .{ }^{1} \mathrm{H}-\mathrm{NMR}(400 \mathrm{MHz}$, $\left.\mathrm{CDCl}_{3}\right) \delta 8.38\left(\mathrm{~s}, 1 \mathrm{H},-\mathrm{C}_{6} \mathrm{H}_{5}\right), 7.48\left(\mathrm{~d}, J=8.7 \mathrm{~Hz}, 2 \mathrm{H},-\mathrm{C}_{6} \mathrm{H}_{5}\right), 7.15\left(\mathrm{~d}, J=8.8 \mathrm{~Hz}, 1 \mathrm{H},-\mathrm{C}_{6} \mathrm{H}_{5}\right)$, $7.10\left(\mathrm{~d}, J=8.7 \mathrm{~Hz}, 2 \mathrm{H},-\mathrm{C}_{6} \mathrm{H}_{5}\right), 6.25\left(\mathrm{dd}, J=8.8,2.5 \mathrm{~Hz}, 1 \mathrm{H},-\mathrm{C}_{6} \mathrm{H}_{5}\right), 6.18(\mathrm{~d}, J=2.5 \mathrm{~Hz}, 1 \mathrm{H}$, $\left.-\mathrm{C}_{6} \mathrm{H}_{5}\right), 3.40\left(\mathrm{q}, \mathrm{J}=7.1 \mathrm{~Hz}, 4 \mathrm{H},-\mathrm{NCH}_{2} \mathrm{CH}_{3}\right), 1.21\left(\mathrm{t}, \mathrm{J}=7.1 \mathrm{~Hz}, 6 \mathrm{H},-\mathrm{NCH}_{2} \mathrm{CH}_{3}\right) .{ }^{13} \mathrm{C}-\mathrm{NMR}$ $\left(100 \mathrm{MHz} \mathrm{CDCl}_{3}\right) \delta 162.90$ (-COO-), 159.82 (-CONH-), 156.78 (-CH=C), $150.96(-\mathrm{CH}=\mathrm{C})$, $147.07(-\mathrm{CH}=\mathrm{C}), 132.87(-\mathrm{CH}=\mathrm{C}), 131.22(-\mathrm{CH}=\mathrm{C}), 121.47(-\mathrm{CH}=\mathrm{C}), 107.93$ (-CH=C), 102.89 $(-\mathrm{CH}=\mathrm{C}), 96.66(-\mathrm{CH}=\mathrm{C}), 43.61\left(-\mathrm{NCH}_{2} \mathrm{CH}_{3}\right), 11.68\left(-\mathrm{NCH}_{2} \mathrm{CH}_{3}\right)$. HR-MS (ESI): calcd for $\mathrm{C}_{20} \mathrm{H}_{20} \mathrm{BrN}_{2} \mathrm{O}_{3}[\mathrm{M}+\mathrm{H}]^{+}:$415.0657; found: 415.0646 .

7-(diethylamino)-N-(4-methoxyphenyl)-2-oxo-2H-chromene-3-carboxamide (12c). Yellow solid; yield 59\%; mp: $189.8-194.0{ }^{\circ} \mathrm{C}$. IR (KBr) $v_{\max }\left(\mathrm{cm}^{-1}\right) 3260,1687,1588 .{ }^{1} \mathrm{H}-\mathrm{NMR}(400 \mathrm{MHz}$, $\left.\mathrm{CDCl}_{3}\right) \delta 8.36\left(\mathrm{~s}, 1 \mathrm{H},-\mathrm{C}_{6} \mathrm{H}_{5}\right), 7.20\left(\mathrm{~d}, J=8.8 \mathrm{~Hz}, 2 \mathrm{H},-\mathrm{C}_{6} \mathrm{H}_{5}\right), 7.14\left(\mathrm{~d}, J=8.5 \mathrm{~Hz}, 1 \mathrm{H},-\mathrm{C}_{6} \mathrm{H}_{5}\right)$, $6.92\left(\mathrm{~d}, J=8.8 \mathrm{~Hz}, 2 \mathrm{H},-\mathrm{C}_{6} \mathrm{H}_{5}\right), 6.24\left(\mathrm{~d}, J=7.6 \mathrm{~Hz}, 2 \mathrm{H},-\mathrm{C}_{6} \mathrm{H}_{5}\right), 3.82\left(\mathrm{~s}, 3 \mathrm{H},-\mathrm{OCH}_{3}\right), 3.40(\mathrm{q}$, $\left.J=7.1 \mathrm{~Hz}, 4 \mathrm{H},-\mathrm{NCH}_{2} \mathrm{CH}_{3}\right), 1.20\left(\mathrm{t}, J=7.1 \mathrm{~Hz}, 6 \mathrm{H},-\mathrm{NCH}_{2} \mathrm{CH}_{3}\right) .{ }^{13} \mathrm{C}-\mathrm{NMR}\left(100 \mathrm{MHz}, \mathrm{CDCl}_{3}\right)$ $\delta 163.14$ (-COO-), 157.48 (-CONH-), 156.78 (-CH=C), 150.87 (-CH=C), 132.70 (-CH=C), 123.34 $(-\mathrm{CH}=\mathrm{C}), 122.45(-\mathrm{CH}=\mathrm{C}), 120.53(-\mathrm{CH}=\mathrm{C}), 113.52(-\mathrm{CH}=\mathrm{C}), 107.84(-\mathrm{CH}=\mathrm{C}), 102.85(-\mathrm{CH}=\mathrm{C})$, $96.90(-\mathrm{CH}=\mathrm{C}), 54.52\left(-\mathrm{OCH}_{3}\right), 43.62\left(-\mathrm{NCH}_{2} \mathrm{CH}_{3}\right), 11.70\left(-\mathrm{NCH}_{2} \mathrm{CH}_{3}\right) . \mathrm{HR}-\mathrm{MS}$ (ESI): calcd for $\mathrm{C}_{21} \mathrm{H}_{23} \mathrm{~N}_{2} \mathrm{O}_{4}[\mathrm{M}+\mathrm{H}]^{+}$: 367.1658; found: 367.1666.

\subsection{Biology \\ 4.2.1. Cell Culture}

MDA-MB-231 (ATCC ${ }^{\circledR}$ HTB-26 $^{\mathrm{TM}}$ ), KB (ATCC ${ }^{\circledR}$ CCL-17 ${ }^{\mathrm{TM}}$ ) and HCT-116 (ATCC ${ }^{\circledR}$ CCL-247 ${ }^{\mathrm{TM}}$ ) cells were purchased from the American Type Culture Collection (ATCC, Manassas, VA, USA). Cells were cultured in Dulbecco's Modified Eagle's Medium (DMEM) media with $10 \%$ fetal bovine serum (FBS), $1 \%$ penicillin/streptomycin at $37{ }^{\circ} \mathrm{C}$ in a $5 \%$ $\mathrm{CO}_{2}$ incubator.

\subsubsection{MTT Assay}

$4 \times 10^{3}$ cells were seeded in each well of the 96-well plate in triplicates followed by $24 \mathrm{~h}$ of incubation. The cells were treated with various concentrations of compounds $(0.78$, $1.56,3.12,6.25,12.50,25.00$, and $50.00 \mu \mathrm{M})$. After a 72-h incubation, 3-(4,5-dimethylthiazol2-yl)-2,5-diphenyltetrazolium bromide (MTT) were added, and the cells were incubated for another $4 \mathrm{~h}$ prior to the addition of DMSO. Absorbance was recorded at a wavelength of $540 \mathrm{~nm}$ with a reference length of $655 \mathrm{~nm}$, and the results shown were collected from three independent experiments. The $\mathrm{IC}_{50}$ was determined by using GraphPad Prism software version 7.0 and nonlinear regression (curve fit).

\subsubsection{Cell Migration Assay}

$5 \times 10^{5}$ MDA-MB-231 cells per well were cultured in a 6-well plate and allowed to reach $80 \%$ confluency for $12 \mathrm{~h}$. The monolayer was then scratched using a $200 \mu \mathrm{L}$ pipet tip to produce a wound. The culture medium was removed, and each plate was washed with phosphate buffer saline (PBS) and treated with different concentrations of compound 9c (5, 
10 , and $20 \mu \mathrm{M})$ for 24 and $48 \mathrm{~h}$, respectively. Images were captured at the identified time point $(0,24$, and $48 \mathrm{~h})$ and processed with the ImageJ software.

\subsubsection{Analysis of Cell Invasion}

For the assay, 24-well transwell chambers coated with $45 \mu \mathrm{L}$ matrigel were used. In brief, $6 \times 10^{4}$ MDA-MB-231 cells per well were seeded in the upper part of the insert filled with $200 \mu \mathrm{L}$ of DMEM without FBS, and for the lower part, the chamber was filled with $600 \mu \mathrm{L}$ DMEM containing $10 \%$ FBS. The cells were allowed to grow for $48 \mathrm{~h}$ followed by treatment with different concentrations of compound $9 \mathrm{c}(5,10$, and $20 \mu \mathrm{M})$. The invaded cells were fixed with paraformaldehyde for $2 \mathrm{~h}$ and stained with crystal violet solution $(0.2 \%)$ for $1 \mathrm{~h}$, and non-invading cells in the top chambers of the transwell plates were scraped away by cotton swabs. Every insert was imaged at $10 \times$ magnification and analyzed using ImageJ software.

\subsubsection{Apoptosis Analysis and Morphology Observation}

$5 \times 10^{5}$ MDA-MB-231 cells per well were seeded in a 6-well plate for $12 \mathrm{~h}$ and were treated with different concentrations of compound $9 \mathrm{c}(5,10,20,40$, and $80 \mu \mathrm{M})$ for $48 \mathrm{~h}$. After treatment, the cells were harvested, washed twice with ice-cold PBS and resuspended in $500 \mu \mathrm{L}$ of $1 \times$ Annexin V binding buffer and then mixed with $5 \mu \mathrm{L}$ of Annexin V-FITC and $5 \mu \mathrm{L}$ of PI solution at room temperature in the dark for $10 \mathrm{~min}$. Then, one part of the cells was immediately analyzed with a flow cytometer. The other part was washed twice with PBS, and the cells were photo-graphed by fluorescence microscope.

\subsubsection{Intracellular ROS Level Detection}

In 6-well plates, $2 \times 10^{5} \mathrm{MDA}-\mathrm{MB}-231$ cells were plated and treated with different concentrations $(0,10,20,30$, and $40 \mu \mathrm{M})$ of compound $9 \mathrm{c}$ for $48 \mathrm{~h}$. ROS assay kit (Beyotime) was used to measure intracellular ROS level. DCFH-DA diluted with serum-free medium with 1:1000 was added into the cells at $37^{\circ} \mathrm{C}$ for $20 \mathrm{~min}$. The cells were collected after washing three times with serum-free medium. Images were acquired using an inverted fluorescence microscope, and the fluorescence intensity was detected at an excitation wavelength of $488 \mathrm{~nm}$ and an emission wavelength of $525 \mathrm{~nm}$ with microplate reader.

\subsubsection{Western Blotting}

For Western blotting analyses, the collected cells were rinsed in PBS and lysed in sodium dodecyl sulfate (SDS) lysis buffer. Equal amounts of protein were separated on $10 \%$ SDS-polyacrylamide gels, transferred to polyvinylidene fluoride (PVDF) membranes, and blocked with 5\% nonfat dry milk in tris-buffered saline and tween 20 (TBST) for $1 \mathrm{~h}$. The membranes were then incubated with primary antibodies (caspase-3, Bcl-2 and $\beta$-actin) overnight at $4{ }^{\circ} \mathrm{C}$. After being washed three times with TBST for $10 \mathrm{~min}$, the membranes were incubated with appropriate secondary antibodies in TBST for $1 \mathrm{~h}$. After several washes of TBST, the blots were developed by enhanced chemiluminescence (ECL) solution.

\subsubsection{Statistical Analysis}

GraphPad Prism software version 7.0 was used to determine the differences between groups. Values with a $p$-value less than 0.05 are considered as significant and statistical significance is represented as ${ }^{* * *}(p<0.0001),{ }^{* * *}(p<0.001),{ }^{* *}(p<0.01),{ }^{*}(p<0.05)$, ns (not significant).

\section{Conclusions}

A novel series of coumarin sulfonamides and amides derivatives were designed and synthesized. Compound $9 \mathrm{c}$ was found to be the most potent derivative, which displayed favorable antiproliferative activities toward MDA-MB-231 cells and inhibited migration and invasion and induced apoptosis in MDA-MB-231 cells. Furthermore, it was verified that compound 9c promoted MDA-MB-231 cell apoptosis by increasing intracellular ROS 
levels and upregulating the expression of caspase-3. This work presents information that is helpful for the design and synthesis of new coumarin derivatives as potential antitumor drug candidates.

Supplementary Materials: The following are available online. ${ }^{1} \mathrm{H}$ - and ${ }^{13} \mathrm{C}-\mathrm{NMR}$ spectra of all compounds.

Author Contributions: Conceptualization, H.J.; methodology, J.Z., G.L., and H.J.; validation, L.C. and M.N.; formal analysis, J.Z.; investigation, J.Z., G.L., and Y.T.; resources, Z.W.; writing-original draft preparation, J.Z.; writing-review and editing, H.J.; supervision, H.J.; project administration, H.J.; funding acquisition, H.J. and Z.W. All authors have read and agreed to the published version of the manuscript.

Funding: This research was funded by the Natural Science Foundation of Guangdong Province (2018A0303130139, 2017A030310488), the Science and Technology Planning Project of Guangdong Province (2015A020211039), Scientific Research Project for Guangzhou Municipal Colleges and Universities (1201610139, 1201630263), Science and Technology Program of Guangzhou (201707010353), and Educational Commission of Guangdong Province (2015KQNCX134).

Institutional Review Board Statement: Not applicable.

Informed Consent Statement: Not applicable.

Data Availability Statement: The data presented in this study are available in Supplementary Materials.

Conflicts of Interest: The authors declare no conflict of interest.

Sample Availability: Samples of the compounds are available from the authors.

\section{References}

1. Varmus, H. The new era in cancer research. Science 2006, 312, 1162-1165. [CrossRef] [PubMed]

2. Kerru, N.; Singh, P.; Koorbanally, N.; Raj, R.; Kumar, V. Recent advances (2015-2016) in anticancer hybrids. Eur. J. Med. Chem. 2017, 142, 179-212. [CrossRef] [PubMed]

3. Hoult, J.R.S.; Payá, M. Pharmacological and biochemical actions of simple coumarins: Natural products with therapeutic potential. Gen. Pharmacol. 1996, 27, 713-722. [CrossRef]

4. Hawryl, M.A.; Soczewinski, E.; Dzido, T.H. Separation of coumarins from Archangelica officinalis in high-performance liquid chromatography and thin-layer chromatography systems. J. Chromatogr. A 2000, 886, 75-81. [CrossRef]

5. Devulapally, S.; Chandraiah, G.; Pramod, K.D. A review on pharmacological properties of coumarins. Mini Rev. Med. Chem. 2018, 18, 113-141.

6. Salem, M.A.I.; Marzouk, M.I.; El-Kazak, A.M. Synthesis and characterization of some new coumarins with in vitro antitumor and antioxidant activity and high protective effects against DNA damage. Molecules 2016, 21, 249. [CrossRef]

7. Emami, S.; Dadashpour, S. Current developments of coumarin-based anti-cancer agents in medicinal chemistry. Eur. J. Med. Chem. 2015, 102, 611-630. [CrossRef]

8. Kasumbwe, K.; Venugopala, K.N.; Mohanlall, V.; Odhav, B. Synthetic mono/di-halogenated coumarin derivatives and their anticancer properties. Anticancer Agents Med. Chem. 2017, 17, 276-285. [CrossRef]

9. Mohamed, T.K.; Batran, R.Z.; Elseginy, S.A.; Ali, M.M.; Mahmoud, A.E. Synthesis, anticancer effect and molecular modeling of new thiazolylpyrazolyl coumarin derivatives targeting VEGFR-2 kinase and inducing cell cycle arrest and apoptosis. Bioorg. Chem. 2019, 85, 253-273. [CrossRef]

10. Elhenawy, A.A.; Al-Harbi, L.M.; El-Gazzar, M.A.; Khowdiary, M.M.; Moustfa, A. Synthesis, molecular properties and comparative docking and QSAR of new 2-(7-hydroxy-2-oxo-2H-chromen-4-yl) acetic acid derivatives as possible anticancer agents. Spectrochim. Acta A Mol. Biomol. Spectrosc. 2019, 218, 248-262. [CrossRef]

11. Maleki, E.H.; Bahrami, A.R.; Sadeghian, H.; Matin, M.M. Discovering the structure-activity relationships of different O-prenylated coumarin derivatives as effective anticancer agents in human cervical cancer cells. Toxicol. In Vitro 2020, 63, 104745. [CrossRef] [PubMed]

12. Mamatha, S.V.; Belagali, S.L.; Mahesh, B.; Kumbar, V.M. Design and synthesis of novel coumarin conjugated acetamides as promising anticancer agents: An in silico and in vitro approach. Anticancer Agents Med. Chem. 2020, 20, 1-10. [CrossRef] [PubMed]

13. Govindaiah, P.; Dumala, N.; Mattan, I.; Grover, P.; Prakash, M.J. Design, synthesis, biological and in silico evaluation of coumarin-hydrazone derivatives as tubulin targeted antiproliferative agents. Bioorg. Chem. 2019, 91, 103143. [CrossRef] [PubMed]

14. García, S.; Mercado-Sánchez, I.; Bahena, L.; Alcaraz, Y.; García-Revilla, M.A.; Robles, J.; Santos-Martínez, N.; Ordaz-Rosado, D.; García-Becerra, R.; Vazquez, M.A. Design of fluorescent foumarin-hydroxamic acid derivatives as inhibitors of HDACs: Synthesis, anti-proliferative evaluation and docking studies. Molecules 2020, 25, 5134. [CrossRef] [PubMed] 
15. Stefanachi, A.; Leonetti, F.; Pisani, L.; Catto, M.; Carotti, A. Coumarin: A natural, privileged and versatile scaffold for bioactive compounds. Molecules 2018, 23, 250. [CrossRef] [PubMed]

16. Touisni, N.; Maresca, A.; McDonald, P.C.; Lou, Y.; Scozzafava, A.; Dedhar, S.; Winum, J.Y.; Supuran, C.T. Glycosyl coumarin carbonic anhydrase IX and XII inhibitors strongly attenuate the growth of primary breast tumors. J. Med. Chem. 2011, 54, 8271-8277. [CrossRef]

17. Musa, M.A.; Cooperwood, J.S.; Khan, M.O.F. A review of coumarin derivatives in pharmacotherapy of breast cancer. Curr. Med. Chem. 2008, 15, 2664-2679. [CrossRef]

18. Sabt, A.; Abdelhafez, O.M.; El-Haggar, R.S.; Madkour, H.M.F.; Eldehna, W.M.; El-Khrisy, E.E.D.A.M.; Abdel-Rahman, M.A.; Rashed, L.A. Novel coumarin-6-sulfonamides as apoptotic anti-proliferative agents: Synthesis, in vitro biological evaluation, and QSAR studies. J. Enzyme Inhib. Med. Chem. 2018, 33, 1095-1107. [CrossRef]

19. Yu, X.M.; Shen, G.; Neckers, L.; Blake, H.; Holzbeierlein, J.; Cronk, B.; Blagg, B.S.J. Hsp90 inhibitors identified from a library of novobiocin analogues. J. Am. Chem. Soc. 2005, 127, 12778-12779. [CrossRef]

20. Peperidou, A.; Bua, S.; Bozdag, M.; Hadjipavlou-Litina, D.; Supuran, C.T. Novel 6- and 7-substituted coumarins with inhibitory action against lipoxygenase and tumor-associated carbonic anhydrase IX. Molecules 2018, 23, 153. [CrossRef]

21. Ji, H.; Tan, Y.; Gan, N.; Zhang, J.; Li, S.; Zheng, X.; Wang, Z.; Yi, W. Synthesis and anticancer activity of new coumarin-3-carboxylic acid derivatives as potential lactatetransportinhibitors. Bioorg. Med. Chem. 2020, 29, 115870. [CrossRef] [PubMed]

22. Wu, Y.; Xu, J.; Liu, Y.; Zeng, Y.; Wu, G. A review on anti-tumor mechanisms of coumarins. Front. Oncol. 2020, 10, 592853. [CrossRef] [PubMed]

23. Zhang, G.; Xu, Y.; Zhou, H.F. Esculetin inhibits proliferation, invasion, and migration of laryngeal cancer in vitro and in vivo by inhibiting janus kinas (JAK)-signal transducer and activator of transcription-3 (STAT3) activation. Med. Sci. Monit. 2019, 25, 7853-7863. [CrossRef] [PubMed]

24. Yao, D.; Pan, D.; Zhen, Y.; Huang, J.; Wang, J.; Zhang, J.; He, Z. Ferulin C triggers potent PAK1 and p21-mediated anti-tumor effects in breast cancer by inhibiting tubulin polymerization in vitro and in vivo. Pharmacol. Res. 2020, 152, 104605. [CrossRef] [PubMed]

25. Elshemy, H.A.H.; Zaki, M.A. Design and synthesis of new coumarin hybrids and insight into their mode of antiproliferative action. Bioorg. Med. Chem. 2017, 25, 1066-1075. [CrossRef] [PubMed]

26. Gupta, S.C.; Hevia, D.; Patchva, S.; Park, B.; Koh, W.; Aggarwal, B.B. Upsides and downsides of reactive oxygen species for cancer: The roles of reactive oxygen species in tumorigenesis, prevention, and therapy. Antioxid. Redox Signal. 2012, 16, 1295-1322. [CrossRef] [PubMed]

27. Han, H.W.; Zheng, C.S.; Chu, S.J.; Sun, W.X.; Han, L.J.; Yang, R.W.; Qi, J.L.; Lu, G.H.; Wang, X.M.; Yang, Y.H. The evaluation of potent antitumor activities of shikonin coumarin-carboxylic acid, PMMB232 through HIF-1 $\alpha$-mediated apoptosis. Biomed. Pharmacother. 2018, 97, 656-666. [CrossRef]

28. Musa, M.A.; Latinwo, L.M.; Joseph, M.Y.; Badisa, V.L. Identification of 7,8-diacetoxy-3-arylcoumarin derivative as a selective cytotoxic and apoptosis-inducing agent in a human prostate cancer cell line. Anticancer Res. 2017, 37, 6005-6014.

29. Talmadge, J.E.; Fidler, I.J. AACR centennial series: The biology of cancer metastasis: Historical perspective. Cancer Res. 2010, 70, 5649-5669. [CrossRef]

30. Parrish, A.B.; Freel, C.D.; Kornbluth, S. Cellular mechanisms controlling caspase activation and function. CSH Perspect. Biol. 2013, 5, a008672. [CrossRef]

31. Wong, R.S.Y. Apoptosis in cancer: From pathogenesis to treatment. J. Exp. Clin. Cancer Res. 2011, 30, 87. [CrossRef] [PubMed]

32. Dong, D.; Dong, Y.; Fu, J.; Lu, S.; Yuan, C.; Xia, M.; Sun, L.K. Bcl2 inhibitor ABT737 reverses the Warburg effect via the Sirt3-HIF1 $\alpha$ axis to promote oxidative stress-induced apoptosis in ovarian cancer cells. Life Sci. 2020, 255, 117846. [CrossRef] [PubMed]

33. Galluzzi, L.; López-Soto, A.; Kumar, S.; Kroemer, G. Caspases connect cell-death signaling to organismal homeostasis. Immunity 2016, 44, 221-231. [CrossRef] [PubMed]

34. Warren, C.F.A.; Wong-Brown, M.W.; Bowden, N.A. BCL-2 family isoforms in apoptosis and cancer. Cell Death Dis. 2019, 10, 177. [CrossRef] [PubMed]

35. Mohan, S.; Abdelwahab, S.I.; Kamalidehghan, B.; Syam, S.; May, K.S.; Harmal, N.S.M.; Shafifiyaz, N.; Hadi, A.H.A.; Hashim, N.M.; Rahmani, M.; et al. Involvement of NF-kB and Bcl2/Bax signaling pathways in the apoptosis of MCF7 cells induced by a xanthone compound Pyranocycloartobiloxanthone A. Phytomedicine 2012, 19, 1007-1015. [CrossRef]

36. Vucicevic, K.; Jakovljevic, V.; Colovic, N.; Tosic, N.; Kostic, T.; Glumac, I.; Pavlovic, S.; Karan-Djurasevic, T.; Colovic, M. Association of Bax expression and Bcl2/Bax ratio with clinical and molecular prognostic markers in chronic lymphocytic leukemia. J. Med. Biochem. 2016, 35, 150-157. [CrossRef]

37. Reddy, N.; Mallireddigari, M.R.; Cosenza, S.; Gumireddy, K.; Bell, S.C.; Reddy, E.P.; Reddy, M.V.R. Synthesis of new coumarin 3-(N-aryl) sulfonamides and their anticancer activity. Bioorg. Med. Chem. Lett. 2004, 14, 4093-4097. [CrossRef]

38. Yang, F.; Rauch, K.; Kettelhoit, K.; Ackermann, L. Aldehyde-assisted ruthenium (II)-catalyzed CH oxygenations. Angew. Chem. Int. Ed. 2014, 126, 11467-11470. [CrossRef]

39. Huang, K.; Liu, M.; Wang, X.; Cao, D.; Gao, F.; Zhou, K.; Wang, W.; Zeng, W. Cascade reaction and FRET-based fluorescent probe for the colorimetric and ratiometric signaling of hydrogen sulfide. Tetrahedron Lett. 2015, 56, 3769-3773. [CrossRef] 